\title{
Hubungan Kadar Procalcitonin dengan Demam Neutropenia pada Leukemia Limfoblastik Akut Anak
}

\author{
Yutta Inten, Lelani Reniarti, Alex Chairulfatah \\ Departemen Ilmu Kesehatan Anak Fakultas Kedokteran Universitas Padjadjaran/Rumah Sakit Dr. Hasan Sadikin, Bandung
}

\begin{abstract}
Latar belakang. Kejadian infeksi bakteri pada leukemia limfoblastik akut (LLA) lebih tinggi pada demam neutropenia (DN). Procalcitonin (PCT) memiliki sensitivitas dan spesifisitas yang lebih baik dibanding dengan C-reactive protein (CRP). Hal ini masih menjadi perdebatan, pada penelitian sebelumnya dinyatakan bahwa CRP lebih baik dibanding dengan PCT.

Tujuan. Menentukan hubungan PCT dengan DN pada LLA anak dengan mengikutsertakan CRP.

Metode. Penelitian potong lintang pada 78 subjek usia 0-13 tahun dengan DN dan demam tanpa neutropenia (DTN) yang memenuhi kriteria inklusi dilakukan pemeriksaan PCT serum. Pemilihan subjek secara consecutive sampling. Variabel dengan nilai p $<0,25$ pada analisis bivariat dilanjutkan analisis multivariat dengan rasio Odds (RO) dan interval kepercayaan (IK) $95 \%$.

Hasil. Di antara 78 pasien LLA didapatkan 27 DN dan 51 DTN. Hubungan kadar PCT dan CRP serum dengan DN berturut-turut RO 3,618 (IK95\%: 1,227-10,665) dan RO 3,676 (IK95\%: 1,22-11,028). Procalcitonin dan CRP memperlihatkan diskriminasi yang baik dengan AUC 0,752 (IK 95\%: 0,639-0,866) serta kalibrasi yang kuat ( $\mathrm{p}=0,692)$.

Kesimpulan. Procalcitonin serum berhubungan dengan DN pada LLA anak yang meningkat hubungannya dengan mengikutsertakan CRP. Sari Pediatri 2015;17(4):267-72.
\end{abstract}

Kata kunci: demam neutropenia, leukemia limfoblastik akut, procalcitonin

\section{The Correlation of Procalcitonin Levels with Febrile Neutropenia in Acute Lymphoblastic Leukemia in Children}

Yutta Inten, Lelani Reniarti, Alex Chairulfatah

Backgroud. Acute lymphoblastic leukemia (ALL) patients with febrile neutropenia (FN) developed bacterial infection more frequently. Procalcitonin (PCT) has a better sensitivity and specificity compare to C-reactive protein (CRP). Prior research stated that CRP is better than PCT hence still in debated.

Objective. To determine corelation of PCT serum with FN in ALL children, with the involvement of serum CRP.

Method. A cross-sectional study with 78 FN and Febrile Without Neutropenia (FWN) aged 0-13 year were tested for serum PCT. Variable with $\mathrm{p}<0.25$ in bivariate analysis proceeded with multivariate analysis using odds ratio $(\mathrm{OR})$ and confidence interval 95\%.

Results. Out of 78 subjects, 27 with neutropenia and 51 without neutropenia. There is correlation between serum PCT and serum CRP level in FN (OR: 3.618; 95\% CI 1,227-10.665) and (OR: 3,676;95\% CI 1,225-11,028). There is good discrimination (AUC 0,752; 95\% CI: 0,639-0,866) and good calibration $(\mathrm{p}=0,692)$.

Conclusion. There is correlation between serum PCT level and FN in ALL children which amplified by the involvement of serum CRP. Sari Pediatri 2015;17(4):267-72.

Keywords: acute lymphoblastic leukemia, febrile neutropenia, procalcitonin

Alamat korespondensi: Dr. Lelani Reniarti, dr, SpA(K), M.Kes. Departemen Ilmu Kesehatan Anak. Fakultas Kedokteran Universitas Padjadjaran/Rumah Sakit Dr. Hasan Sadikin. Jl. Pasteur No. 38 Bandung 40163. Tel.+62-22-3035957. Alamat E-mail: lelanir@yahoo.com 
L eukemia limfoblastik akut (LLA) merupakan keganasan yang paling sering ditemukan pada anak (97\%). ${ }^{1}$ Setiap tahun di Asia ditemukan 1000 kasus LLA pada anak. Selama tahun 2010-2011, Rumah Sakit Dr. Hasan Sadikin Bandung mendapatkan 51 kasus baru LLA. ${ }^{2}$ Penderita LLA yang menjalani kemoterapi ataupun tidak memiliki risiko terjadi demam neutropenia (DN). Kejadian DN pada LLA anak di RS Kanker Dharmais Jakarta adalah 60\%. ${ }^{3}$ Penelitian di Amerika Serikat ditunjukkan bahwa angka mortalitas akibat DN sebesar 9,5\%. Data dari European organization for research and treatment of cancer (EORTC) angka mortalitas 8,5\%, sedangkan di Singapura 8,8\%.4,5 Di Rumah Sakit Cipto Mangunkusumo, angka mortalitas 34\%, sedangkan di Rumah Sakit Hasan Sadikin didapatkan $48 \%{ }^{6}$

Makin rendah nilai ANC kemungkinan infeksi bakteri menjadi lebih tinggi sehingga pada DN pemberian antibiotik segera sudah merupakan konsensus. ${ }^{7-10}$ Namun, tidak semua pasien LLA dengan DN disebabkan infeksi bakteri, hal ini karena kejadian infeksi bakteri pada DN berkisar 30\%-60\%., ${ }^{7,10,11}$ Demam pada LLA anak dapat disebabkan keganasannya sendiri (tumor related fever). ${ }^{12}$ Oleh karena itu, pasien LLA yang mengalami DN harus tetap dicari apakah penyebabnya infeksi atau bukan.

Faktor yang berhubungan dengan infeksi bakteri pada DN yaitu keadaan klinis anak. Makin toksik klinis anak maka kemungkinan infeksi bakteri makin besar. ${ }^{13}$ Pada LLA, kejadian infeksi bakteri berat yang sering ditemukan adalah sepsis dan pada DN kejadian sepsis cukup tinggi (25\%). ${ }^{14}$ Sepsis merupakan kondisi yang memperberat pasien LLA dengan DN. ${ }^{8}$ Diagnosis infeksi bakteri pada DN yang sulit memerlukan petanda diagnostik dengan sensitivitas dan spesifisitas yang tinggi sehingga diharapkan penegakan diagnosis infeksi bakteri dapat lebih dini. Petanda diagnostik infeksi bakteri yang sudah digunakan secara luas adalah $C$-reactive protein (CRP) dan procalcitonin (PCT), tetapi pada penelitian sebelumnya masih diperdebatkan apakah PCT lebih baik dibanding dengan CRP, ataukah CRP yang lebih baik untuk mendeteksi infeksi bakteri dibanding dengan PCT pada pasien demam neutropenia. Boysen $\mathrm{dkk}^{15}$ melaporkan bahwa dari 9 penelitian didapatkan 4 penelitian yang menyatakan PCT lebih superior dibanding dengan CRP untuk membedakan infeksi bakteri dengan berbagai penyebab demam lainnya. Meidani $\mathrm{dkk}^{8}$ melaporkan bahwa
PCT dapat digunakan sebagai petanda diagnosis sepsis pada pasien keganasan dengan neutropenia. ${ }^{16}$ Kim $\mathrm{dkk}^{17}$ melaporkan bahwa AUC PCT 0,74 lebih baik dibandingkan dengan AUC CRP 65,5. Penelitian Erten $\mathrm{dkk}^{18}$ melaporkan AUC CRP lebih baik dibanding dengan AUC PCT (85,3 vs 60,3). Penelitian terdahulu pada anak hanya mengenai hubungan PCT dengan CRP pada keganasan, tetapi belum ada yang khusus pada LLA. Penelitian mengenai hubungan PCT dan CRP dengan DN pada pasien LLA anak di Rumah Sakit Dr. Hasan Sadikin Bandung belum terungkap.

Tujuan penelitian untuk menentukan hubungan PCT dengan DN pada LLA anak dengan mengikutsertakan CRP.

\section{Metode}

Penelitian dilakukan di Departemen/SMF Ilmu Kesehatan Anak Rumah Sakit Dr. Hasan Sadikin Bandung pada bulan Agustus 2014-Januari 2015. Orangtua atau wali memberikan persetujuan tertulis (informed consent) setelah diberi informasi secara lengkap dan mengerti keikutsertaan anaknya dalam penelitian ini. Kriteria inklusi adalah pasien LLA $\leq 14$ tahun yang mengalami DN dan demam tanpa neutropenia (DTN) yang belum mendapat antibiotik, sedangkan kriteria eksklusi adalah pasien demam yang secara klinis jelas disebabkan infeksi virus dan demam karena reaksi transfusi. Dikatakan DN apabila absolute neutrophil count (ANC) kurang dari $500 / \mu \mathrm{L}$ atau $<1000 / \mu \mathrm{L}$ dan cenderung turun menjadi di bawah $500 / \mu \mathrm{L}$ dalam waktu 48 jam setelah mulai demam. ${ }^{19-}$ ${ }^{21}$ Pasien dinyatakan sepsis apabila didapatkan infeksi bakteri berat yang didasarkan systemic inflamatory respons syndroms (SIRS) disertai bukti mikrobiologis atau secara klinis sepsis. Kriteria SIRS ditegakkan bila ditemukan dua pengukuran yang abnormal salah satunya suhu atau leukosit dan salah satu dari takikardia, takipnea, atau neutrofil imatur ditambah terdapat bukti mikrobiologis. ${ }^{22,23}$

Penelitian ini berupa observasional analitik rancangan potong lintang. Pemilihan sampel dilakukan secara consecutive sampling pada semua pasien LLA yang memenuhi kriteria inklusi yang dirawat di Ruang Rawat Anak Rumah Sakit Dr. Hasan Sadikin Bandung. Identitas subjek dicatat, meliputi nama, nomor rekam medis, usia, dan jenis kelamin, kemudian dilakukan anamnesis, pemeriksaan fisis, serta pemeriksan 
laboratorium, yaitu biakan darah, ANC, CRP, dan PCT. Procalcitonin serum diukur dengan metode ECLIA (Cobas e411). C-reactive protein serum diukur dengan metode turbidimetri (Cobas Integra).

Perhitungan ukuran sampel ditentukan berdasarkan rumus regresi logistik dengan menetapkan $\mathrm{Z} \propto$ 5\%, Zß 20\%, prevalensi demam neutropenia pada LLA sebanyak $60 \%{ }^{3}$, dan prevalensi infeksi bakteri pada demam neutropenia $50 \%, 8,10,11$ nilai RO minimal yang dianggap bermakna 3,6 ${ }^{17}$ maka didapatkan jumlah sampel minimal 78 subjek. Semua variabel dianalisis menggunakan uji chi-square untuk data kategorik dan uji Mann Whitney untuk data nonkategorik. Variabel dengan analisis bivariat memiliki nilai $\mathrm{p}<0,25$. Setelah itu, dianalisis kembali menggunakan analisis multivariat regresi logistik untuk mengetahui variabel mana yang berhubungan

Tabel 1. Karakteristik subjek penelitian

\begin{tabular}{ccc}
\hline Variabel & $\begin{array}{c}\text { Demam } \\
\text { neutropenia } \\
(\mathrm{n}=27)\end{array}$ & $\begin{array}{c}\text { Demam tanpa } \\
\text { neutropenia } \\
(\mathrm{n}=51)\end{array}$ \\
\hline Jenis kelamin & & \\
Laki-laki & 13 & 30 \\
Perempuan & 14 & 21 \\
Usia (tahun) & & \\
$\leq 1$ & - & 5 \\
$1-2$ & - & 8 \\
$2-3$ & 2 & 6 \\
$3-4$ & 6 & 8 \\
$4-5$ & 3 & 4 \\
$5-10$ & 11 & 14 \\
$>10$ & 5 & 6 \\
\hline
\end{tabular}

dengan demam neutropenia. Variabel PCT dan CRP diubah dari data numerik menjadi data kategorik berdasarkan cut-off point yang didapatkan dari kurva receiver operating characteristic (ROC). Setiap variabel yang berhubungan dengan DN dinyatakan sebagai rasio Odd (RO) dengan interval kepercayaan 95\%. Diskriminasi ditentukan menggunakan analisis ROC dan kalibrasi dengan Hosmer and Lameshow test. Semua analisis data menggunakan program SPSS for windows versi 17.0.

Penelitian mulai dilaksanakan setelah mendapat persetujuan Komite Etik Penelitian Kesehatan Fakultas Kedokteran Universitas Padjadjaran/RS Dr. Hasan Sadikin Bandung.

\section{Hasil}

Penelitian ini dilakukan pada 78 pasien LLA yang memenuhi kriteria inklusi yang terdiri atas 27 subjek DN dan 51 subjek DTN. Empat puluh tiga subjek adalah laki-laki dan 35 subjek perempuan. Usia terbanyak pada kelompok 5-10 tahun (Tabel 1).

Kadar PCT serum ditemukan lebih tinggi secara bermakna pada kelompok sepsis dibanding dengan

Tabel 2. Perbedaan kadar procalcitonin antara kelompok sepsis dan nonsepsis

\begin{tabular}{lccc}
\hline $\begin{array}{l}\text { Procalcitonin } \\
(\mathrm{ng} / \mathrm{mL})\end{array}$ & $\begin{array}{c}\text { Sepsis } \\
(\mathrm{n}=20)\end{array}$ & $\begin{array}{c}\text { Non-sepsis } \\
(\mathrm{n}=58)\end{array}$ & $\begin{array}{c}\text { Nilai } \\
\mathrm{p}^{*}\end{array}$ \\
\hline Rerata & 13,2 & 7,4 & 0,030 \\
Median & 1,6 & 0,5 & \\
Rentang & $0,1-100$ & $0,06-100$ & \\
\hline
\end{tabular}

Keterangan: * Uji Mann-Whitney

Tabel 3. Variabel yang berhubungan dengan DN

\begin{tabular}{llll}
\hline Variabel & $\begin{array}{l}\text { Demam } \\
\text { neutropenia } \\
(\mathrm{n}=27)\end{array}$ & $\begin{array}{l}\text { Demam } \\
\text { tanpa neutropenia } \\
(\mathrm{n}=51)\end{array}$ & Nilai $\mathrm{p}^{*}$ \\
\hline $\begin{array}{l}\text { Procalcitonin }(\mathrm{ng} / \mathrm{mL})^{* *} \\
\quad \leq 0,504\end{array}$ & 7 & & \\
$\quad>0,504$ & 20 & 32 & 0,002 \\
CRP $(\mathrm{mg} / \mathrm{dL})^{* *}$ & & 19 & \\
$\quad \leq 60,6$ & 13 & & 0,002 \\
$>60,6$ & 14 & 42 & \\
\hline Keterangan: ${ }^{*}$ Uji chi-square & & 9 &
\end{tabular}


kelompok nonsepsis (Tabel 2). Variabel PCT dan CRP serum pada analisis bivariat memiliki nilai $\mathrm{p}<0,25$. Cut-off point PCT dan CRP serum pada penelitian ini adalah $>0,504 \mathrm{ng} / \mathrm{mL}$ dan $>60,6 \mathrm{mg} / \mathrm{dL}$ berdasarkan kurva ROC (Tabel 3). Procalcitonin dan CRP selanjutnya dianalisis multivariat dan didapatkan PCT ( $p=0,020$; RO 3,618; IK95\% 1,227-10,665) dan CRP ( $p=0,020$; RO 3,676; IK95\% 1,225-11,028) memiliki hubungan yang bermakna dengan DN (Tabel 4). Persamaan regresi memiliki diskriminasi sedang yaitu AUC 0,752 (IK95\%, 0,639-0,866) dan kalibrasi yang kuat $(\mathrm{p}=0,692)$.

Tabel 4. Analisis multivariabel faktor yang berhubungan dengan DN

\begin{tabular}{lcc}
\hline Variabel & Nilai p & RO (IK95\%) \\
\hline PCT & 0,020 & $3,618(1,227-10,665)$ \\
CRP & 0,020 & $3,676(1,225-11,028)$ \\
Constant & $<0,001$ & 0,167 \\
\hline
\end{tabular}

Keterangan: Kalibrasi dengan Hosmer and Lameshow test, $\mathrm{p}=$ 0,692

Diskriminasi AUC (IK 95\%) = 0,752 (0,639-0,866)

\section{Pembahasan}

Pasien dengan immunocompromised seperti pasien LLA mengalami penurunan sistem pertahanan tubuh terhadap infeksi yang merupakan faktor risiko terjadi infeksi bakteri yang berat. ${ }^{24}$ Pada kasus LLA, timbulnya demam dapat merupakan suatu gejala awal infeksi bakteri. Demam pada pasien neutropenia mungkin merupakan awal dan satu-satunya tanda infeksi bakteri, terutama pada anak. ${ }^{25}$ Anak dengan keganasan yang menjalani kemoterapi intensif memiliki kemungkinan 6 kali lebih besar untuk terjadi sepsis dibanding dengan yang tidak mendapatkan kemoterapi. ${ }^{26}$

Procalcitonin merupakan suatu prohormon dari calcitonin yang disekresikan dari sel C glandula tiroid dan telah diketahui merupakan petanda untuk mendiagnosis infeksi bakteri. Lodahl dan Schroder ${ }^{27}$ menemukan sensitivitas PCT 95\% dengan nilai prediksi positif $67 \%$. Hatzistilianou $\mathrm{dkk}^{24}$ melaporkan nilai prediksi positif sebagai petanda infeksi bakteri sebesar 100\%. American college of critical care medicine (ACCM) dan The infectious disease society of America (IDSA) melaporkan PCT memiliki level of evidence 2 dan merekomendasikan bahwa PCT dapat digunakan sebagai petanda untuk mendiagnosis infeksi bakteri yang merupakan penyebab demam atau gambaran klinis sepsis. ${ }^{25}$

C-reactive protein merupakan reaktan fase akut yang ditemukan di dalam darah diproduksi oleh hepatosit akibat infeksi atau kerusakan jaringan. ${ }^{28}$ Kohli $\mathrm{dkk}^{29}$ melaporkan sensitivitas CRP $\geq 40 \mathrm{mg} / \mathrm{dL}$ dalam mendiagnosis bakteremia adalah 95\% dengan nilai duga positif (NDP) 67\%. Apabila dibandingkan dengan metode lain yang sering digunakan, seperti jumlah leukosit atau petanda inflamasi lainnya, PCT dan CRP serum memiliki sensitivitas dan spesifisitas yang baik untuk memprediksi infeksi bakteri pada anak yang mengalami demam tanpa ditemukan fokus infeksi. ${ }^{18}$

Kejadian infeksi bakteri berat yang paling sering ditemukan pada LLA adalah sepsis dan pada DN kejadian sepsis sekitar 25\%. ${ }^{14}$ Kejadian sepsis pada DN penelitian kami lebih tinggi daripada penelitian yang dilakukan oleh Santolaya. ${ }^{14}$ Hasil penelitian kami menunjukkan kadar PCT serum lebih tinggi secara bermakna pada kelompok sepsis. Tidak jauh berbeda dengan penelitian Giamarellou $\mathrm{dkk}^{30}$ pada subjek anak dengan keganasan yang mengalami DN, yaitu kadar PCT rata-rata pada kelompok sepsis berat 2,62 ng/mL dan $0,57 \mathrm{ng} / \mathrm{mL}$ pada kelompok infeksi terlokalisir.

Didapatkan pasien LLA sama-sama memiliki kemungkinan terjadi DN 3,6 kali, dengan kata lain peningkatan PCT serum pada LLA pada DN menunjukkan sepsis. Kim dkk, ${ }^{17}$ dalam laporan penelitiannya pada subjek DN dewasa, mendapatkan bahwa kadar PCT serum $>0,5 \mathrm{ng} / \mathrm{mL}$ memiliki kemungkinan infeksi bakteri sekitar 3,6 kali.

Area under curve PCT lebih lemah dibandingkan dengan AUC CRP. Namun, AUC saat digabungkan PCT dan CRP serum adalah 0,752 lebih kuat dibanding dengan CRP saja atau PCT serum saja sehingga pemeriksaan PCT bersama CRP serum memiliki hubungan yang saling memperkuat DN pada LLA.

Becker $\mathrm{dkk}^{31}$ melaporkan bahwa kombinasi pemeriksaan PCT dan CRP merupakan petanda yang lebih baik bila digunakan untuk mendiagnosis suatu infeksi. Beberapa penelitian juga menyarankan untuk menggunakan kombinasi PCT dan CRP sebagai metode diagnostik yang lebih akurat. ${ }^{8}$

Keterbatasan penelitian ini yaitu pemilihan subjek penelitian dilakukan dengan tidak memperhatikan lama demam yang dapat memengaruhi hasil penelitian. Lama demam memengaruhi kadar PCT sehubungan dengan waktu paruh yang dimilikinya. 


\section{Kesimpulan}

Procalcitonin berhubungan dengan demam neutropenia pada LLA anak dan hubungannya meningkat apabila bersamaan dengan CRP.

\section{Daftar pustaka}

1. Lanzkowsky P. Manual of pediatric hematology and oncology. Edisi kelima. New York: Churchill Livingtone; 2011.h.518-49.

2. Pernomo B, Ugrasena I. penyunting. Buku ajar hematoonkologi anak 3. Jakarta: IDAI; 2010.h.23445.

3. Mulyani, Aryani D, Andalusia R. Evaluasi penggunaan antibiotik pada pasien pediatri leukemia limfoblastik akut dengan febrile neutropenia selama pemberian kemoterapi di Rumah Sakit Kanker Dharmais Jakarta. Media Farmasi 2014;11:98-107.

4. Anna F, Luaces C, Garcia J. Procalcitonin in pediatric emergency departements for the early diagnosis of invasive bacterial infections in febrile infants: results of a multicenter study and utility of a rapid qualitative test for this marker. Pediatr Infect Dis J 2003;22:895-903.

5. Van D, Witte M, Kremer L, Offringa M, Scholten R, Caron H. Efficacy of oral prophylatic antibiotics in neutropenic afebrile oncology patients: a systematic review of randomised controlled trials. Eur J Cancer 2005;41:1372-82.

6. Stefanus G, Novie H, Max F, Rampenga T. Febrile neutropenia in childhood leukemia: Manado experience 1997-2006. Pediatr Indones 2009;49:372-8.

7. Robinson JO, Lamoth F, Bally F, Knaup M, Calandra $\mathrm{T}$, Marchetti O. Monitoring procalcitonin in febrile neutropenia: What is its utility for initial diagnosis of infection and reassesment in persistent fever. Plos One 2011;6:1-9.

8. Meidani M, Khorvash F, Abolghasemi H, Jamali B. Procalcitonin and quantitative C-reactive protein role in the early diagnosis of sepsis in patients with febrile neutropenia. SAJC 2013;2:216-9.

9. Kitanovski L, Jazbee J, Hojker S, Dergane M. Diagnostic accuracy of lipopolysaccharide-binding protein for predicting bacteremia/clinical sepsis in children with febrile neutropenia: comparison with interleukin-6, procalcitonin, and C-reactive protein. Support Care Cancer 2014;22:269-77.

10. Urbonas V, Eidukaite A, Tamuliene I. The predictive value of soluble biomarkers (CD14 subtype, interleukin-2 receptor, human leucocyte antigen-G) and procalcitonin in the detection of bacteremia and sepsis in pediatric oncology patients with chemotherapy-induced febrile neutropenia. Cytokine 2013;62:34-7.

11. Hadir M, Ibrahim A, Hala M, Meer H, Al-Mobarak M. Fever and granulocytopenia in children with acute lymphoblastic leukemia under induction therapy. Saudi J Med 2001;22:423-7.

12. Shomali W, Hachem R, Chaftari A-M, Jiang Y, Bahu $\mathrm{R}$, Jabbour J. Can procalcitonin distinguish infectious fever from tumor-related fever in non-neutropenis cancer patients? Cancer 2012;1:5823-9.

13. Barraf L. Practice guidelines for the management of infant and children 0-36 months of age with fever without source. Agency for healthcare policy and research. Ann Emerg Med 1993;22:1198-210.

14. Santolaya M, Alvarez A, Becker A, Cofre J, Enri'quez N, O'Ryan M. Prospective, multicenter evaluation of risk factors associated with invasice bacterial infection in children with cancer, neutropenia, ad fever. J Clin Oncol 2001;19:3415-21.

15. Boysen AK, Jensen BR, Paulsen L, Jensen P. Procalcitonin as a marker of infection in febrile neutropenia: a systematic review. Modern Chemother 2013;2:8-14.

16. Chaudhury A, Sumant S, Jayaprada R, Kalawat U. Procalcitonin in sepsis and bacterial infections. J Clin Sci Res 2013;2:216-24.

17. Kim DY, Lee Y-S, Ahn S, Chun YH, Lim KS. The usefulness of procalcitonin and C-reactive protein as early diagnostic markers of bacteremia in cancer patients with febrile neutropenia. Cancer Res Treat 2011;43:176-80.

18. Erten N, Genc S, Besisik SK, Saka B, Karan MA, Tascioglu C. The predictive and diagnostic values of procalcitonin and C-reactive protein for clinical outcome in febrile neutropenic. J Chin Med Assoc 2004;67:21721.

19. Dale D, Cottle T, Fier C. Severe chronic neutropenia : treatment and follow up of patients in the severe chronic neutropenia international registry. Am J Hematol 2003;72:82-93.

20. Hamidah A, Rizal A, Nordiah A. Piperacillin-tazobactam plus amikasin as an initial empirical therapy of febrile neutropenia in paediatric cancer patients. Singapure Med J 2008;49:26-30.

21. Dilek G, Kamer M, Hilal C, Hatice A, Deniz A, Olgun N. Febrile neutropenic episodes in children with lymphoma and malignant solid tumors. J Pediatr Infect 2010;4:1-8. 
22. Long SS, Pickering LK, Prober CG. The systemic inflammatory respons syndrome (SIRS), sepsis, and septic shock. Dalam: Gusman J, penyunting. Principles and practice of pediatric infectious diseases. Edisi keempat. Philadelphia: Saunders; 2012.h. 97-9.

23. Goldstein B, Giroir B, Randolp A. International pediatric sepsis consensus conference: definition for sepss and organ dysfunction in pediatrics. Pediatr Crit Care Med. 2005;6:2-8.

24. Hatzistilianou M, Rekleity A, Athanassiadou F, Lutiis MAD, Conti P, Catriu D. Serial procalcitonin responses in infection of children with secondary immunodeficiency. Clin Invest Med 2007;30:E75-85.

25. Shehabi Y, Seppelt I. Pro/con debate: is procalcitonin useful for guiding antibiotic decison making in critically ill patients? Crit Care 2008;2:211-6.

26. Mendez AVA, Sapolnik R, Mendonca N. New guidelines for the clinical management of febrile neutropenia and sepsis in pediatric oncology patiens. J Pediatr 2007;83:554-63.

27. Lodahl D, Schroder H. Procalcitonin adds to diagnosis, but does not reduce initial antibiotics in febrile neutropenic children. Danish Medical Bulletin 2011;58:1-5.

28. Albarran MM, Molina JP, Castorena SG, Zubieta FS. Procalcitonin and C-reaktive protein serum levels as a markers of infection in a pediatric population with febrile neutropenia and cancer. J Pediatr Hematol Oncol 2009;26:412-25.

29. Kohli V, Singhi S, Sharma P, Ganguly N. Value of serum C-reactive protein concentration in febrile children without apparent focus. Ann Trop Paediatr 1993;13:373-8.

30. Giammarellou H, Giamarellos-Bourboulis EJ, Repoussis P, Galani L, Anagnostopoulos N, Greka P, dkk. Potential use of procalcitonin as a diagnostic criterion in febrile neutropenia: experience from a multicentre study. Clin Microbiol Infect 2004;10:628-33.

31. Becker K, Snider R, Nylen E. Procalcitonin assay in systemic inflammation, infection, and sepsis: clinical utility and limitations. Crit Care Med 2008;36:94152. 